\title{
The relevance of Regional Political Ecology for agriculture and food systems
}

\author{
Ryan E. Galt ${ }^{1}$ \\ University of California, Davis, USA
}

\begin{abstract}
The region as a concept continues to hold promise as a way of breaking through the many binaries that often divide political ecology. Operationalizing a regional political ecology approach allows the researcher to generate a large number of insights and conclusions that a more narrow disciplinary (disciplined) focus and non-scalar approach would miss; this is because important biophysical and social processes intersect with each another and work together to produce and/or mediate important outcomes for human and environmental well-being. The article draws on a number of cases to examine what comparison of political ecological research between regions could look like. I argue for a reinvigorated relationship between regional political ecology as an approach and agrifood systems as the object of study, and pose questions that can help shape this endeavor.
\end{abstract}

Keywords: regional political ecology, regional comparisons, network political ecology, agriculture, food systems, agroecology

\section{Résumé}

La région, en tant que concept, continue de tenir ses promesses comme un moyen de dépasser les divers concepts binaires qui divisent souvent l'écologie politique. L'opérationnalisation d'une approche régionale de l'écologie politique permet au chercheur de générer un grand nombre de points de vue et de conclusions qu'une démarche plus étroite et plus disciplinaire (disciplinée) et une approche non-scalaire ne pourraient pas atteindre; et ce parce que certains processus biophysique et sociaux interagissent entre eux et fonctionnent ensemble pour produire et/ou arbitrer des conséquences majeures pour le bien-être des populations et de l'environnement. Cet article s'appuie sur de nombreux cas pour examiner ce à quoi pourrait rassembler la recherche en écologie politique comparant différentes régions. Je plaide en faveur d'une relation revigorée entre l'écologie politique en tant qu'approche et les systèmes agro-alimentaires en tant qu'objets de recherche, et pose des questions qui peuvent aider à structurer ces efforts.

Mots-clés: écologie politique régionale, comparaisons régionales, écologie politique de réseaux, agriculture, systèmes alimentaires, agroécologie.

\section{Resumen}

El concepto de región sigue siendo útil como manera de romper las polarizaciones que dividen a la ecología política. Poniendo una perspectiva de la ecología política en operación permite el investigador a generar data y conclusiones que no están al alcance de un acercamiento más limitado. Esto se debe al hecho de que hay procesos biofísicos y sociales que trabajan juntos para producir o influir en el bienestar ambiental y humano. Este artículo utiliza varios casos para explorar la comparación de investigaciones en la ecología política entre regiones. Aboga por una relación más robusta entre la ecología política regional y el estudio de los sistemas agroalimentarias, y ofrezco preguntas para orientar este acercamiento.

Palabras Clave: ecologia politica regional, comparación regional, ecologia politica de las redes, agricultura, sistemas alimentarias, agroecología.

\footnotetext{
${ }^{1}$ Dr. Ryan Galt, Associate Professor and MacArthur Foundation Endowed Chair in Global Conservation and Sustainable Development, Department of Human Ecology and Agricultural Sustainability Institute, University of California, 1309 Hart Hall, One Shields Ave., Davis, CA 95616, USA. Email: regalt "at" ucdavis.edu. I'm thankful to Innisfree McKinnon and Colleen Hiner for many things, including: organizing and including me the 2014 AAG sessions of which these thoughts were a part, putting together this Special Section, and providing very helpful editorial comments. I am also thankful for anonymous reviewers' comments. All shortcomings of the article remain my responsibility. This is the third article in Colleen Hiner and Innisfree McKinnon (eds.) 2016. "(Re)considering regional political ecology?", Special Section of the Journal of Political Ecology 23: 115-203.
} 


\section{Introduction}

Regional political ecology grew out of efforts to understand largely peasant societies and the ways in which capital and the state created political economic structures for surplus extraction that were incompatible with long-term conservation and sustainability (Blaikie 1985; Blaikie and Brookfield 1987). Despite the various binaries that have structured political ecological imaginaries since then, I agree with Walker (2003) and McKinnon and Hiner (2016) that the region endures as a way of productively working through the false binaries. This article serves to set regional political ecology within my own experience and explore the ways it has been useful and can be made even more useful through a networked political ecology approach.

\section{The region in political ecology: some personal experiences}

The following three vignettes provide some context for my thoughts about the question posed by Hiner and McKinnon in this special section. Hesitantly but with much excitement, I took my first graduate seminar in the spring of 1999 while an undergraduate in geography at UC Berkeley. Despite my misgivings, my faculty advisor, Professor Bob Reed, thought I could hold my own with graduate students, and was kind enough to encourage me to join in a semester-long, book-a-week, discussion-based seminar. We read a number of foundational books like Marsh's (1998) Man and nature and Glacken's (1967) Traces on the Rhodian shore, but I fondly remember one of the less-famous ones, Dan Stanislawski's Landscapes of Bacchus: the vine in Portugal (1970). It is a Sauerian regional geographic description of agrarian landscapes of grape production, including the Duoro Valley in Northern Portugal. I'll never forget the sweeping vistas, captured in black and white photos, of heavily terraced hillsides dedicated to grapes grown mostly for port. Upon visiting Portugal in 2010, I made the long drive north to see the landscape in person (Figure 1). In comparing the photos of the region to my birth region of the San Joaquin Valley of California, also a Mediterranean-climate region largely dedicated to agriculture but one with an incredibly different landscape, I saw that regions matter because, on the one hand, biophysical environments provide dramatically different conditions for the possibilities of human habitation and use of the land, and, on the other, human modifications iteratively shape these possibilities (see also Thomas et al. 1956). In the case of the Duoro Valley, terraces have transformed a very steep, hilly landscape into one of intense cultivation, while in the San Joaquin Valley, the draining of wetlands, damming of rivers, and building of massive state-created irrigation infrastructure support mostly large-scale, capital-intensive agriculture (Walker 2004).

About six months after the class, in fall of 1999, I excitedly started graduate school. I quickly learned about regional political ecology by taking a class with my new mentor, Professor Karl Zimmerer, at the University of Wisconsin-Madison. During those first few weeks of rapidly changing Wisconsin fall weather (including snow in early October!), in my mind I saw a merging of the ideas of political economy from my recent Berkeley classes with a cultural ecology that had some of its roots in Sauer's Berkeley school of geography (Zimmerer 1996). I was immediately smitten with regional political ecology, and had the strong feeling that I had found an academic home that I could stay in for a long time.

Fast forward four years, when I was attempting to employ regional political ecology's rather everything-but-the-kitchen-sink methodological approach in my dissertation fieldwork. I decided to examine the ways that agrarian capitalism, food safety standards, and the biophysical environment shaped pesticide use - for export and national market — in the most prominent vegetable growing region in Costa Rica. A regional political ecology approach expressed through my fieldwork allowed me to generate a large number of insights and conclusions that a more narrow disciplinary (disciplined) focus and non-scalar approach would have missed, since the all-too-common blinders of narrow disciplines would not have allowed to me to look at the ways that important biophysical and social processes intersected with each another and worked together to produce and/or mediate important outcomes for human and environmental well-being within the region (Galt 2014). This field experience created an enduring bond between my preferred ways of thinking and regional political ecology, entirely bypassing the disillusionment phase (Robbins and Bishop 2008). 


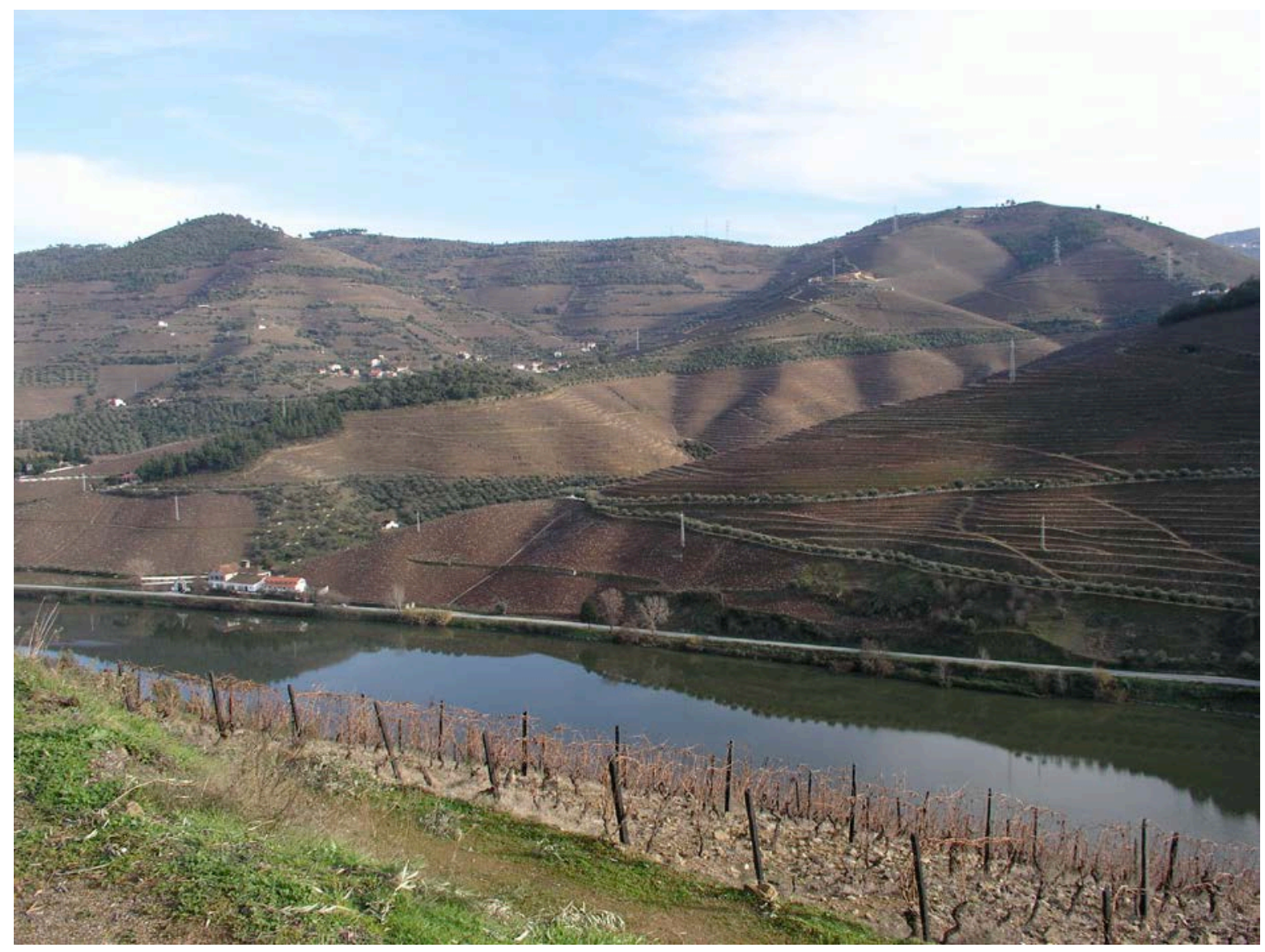

Figure 1: The Duoro Valley, northern Portugal, December 2010.

\section{Why regional approaches matter}

During my research in Costa Rica, I found that thinking spatially and paying attention to the region (as both a conceptual tool and a material reality) allowed me to do a number of important things. These included:

(1) bounding the study to a region where the findings could be generalized, which was to the area where vegetables are commonly grown, a product of the spatial processes of capitalism expanding through pesticide use into territories with difficult climates (Galt 2014) and bounded by more-or-less natural vegetation on most sides, except where it is bounded by an urban area;

(2) conceiving of the region in a more classical regional geography sense as a highland region in Central America, thereby sharing similarities with similar regions as described by Horst (1987);

(3) understanding the spatial areas over which the more than thirty crops are grown as overlapping patchworks (Zimmerer 1999), which was at a finer-grained spatial scale than the study region; and

(4) inductively discovering important spatial variations in climate over the larger production region. 
In other words, a regional approach allowed me to conceptualize a fluid but bounded region (even if the boundaries are socially constructed), homogeneous in its dedication to vegetable farming and similar to other highland Latin American vegetable-growing regions, and, at the same time, it also helped me see the ways in which processes and patterns were spatially heterogeneous within this region. Paying attention to the spatialities of the region and within-region areas allowed me to understand the specificities of the humanenvironment interactions there, and the ways that they might compare with similar assemblages in other regions (Galt 2014).

Speaking more broadly, in the sixteen years I've been interested in political ecology I've found that the regional context is extraordinarily important. On the one hand, there will always be a common-sensical answer to the question of whether regions matter, at least for those of us who are attentive to spatial variation. Clearly there are scales at which processes operate whose spatial extents position them between the general size ranges of nation states and smaller-scale compilations of the urban, the local, and/or the community. On the other hand, there is a more complex reason why regions matter, and this has to do with the ways in which the earth and human society upon it are spatially heterogenous. Geographers are well aware of the regional variation of almost all phenomena over the earth's surface. Climate drives much of this, especially in its overlap with geomorphology and soils, which together largely determine the biological possibilities on the earth's surface, and therefore its ecosystems and biomes. Blaikie and Brookfield (1987: 17) capture some of this on the same page as their oft-cited definition of regional political ecology:

...'regional' is important because it is necessary to take account of environmental variability and the spatial variations in resilience and sensitivity of the land, as different demands are put on the land through time. ... [It] also implies the incorporation of environmental considerations into theories of regional growth and decline.

Thus, the biophysical environment is the context in which humans make their homes, polities, economies, and such. Yet, it is also heavily modified by society (Lowdermilk 1953; Marsh 1998; Sauer 1938; Thomas et al. 1956). Use of tremendous amounts of energy - today and in recent history in the form of fossil fuels - allows us to modify some regional characteristics and make them more amenable to certain human desires, but only at tremendous cost. For this reason, variations in landscapes and the biophysical processes that shape them continue to matter in shaping human activity, and will not be easily removed even by the most ardent human interventions. Thus, regions will continue to matter, arguably more so as our fossil energy reserves wane, or as we take the responsible course of action and leave them in the ground to not further disrupt our climate. This makes it very important to have an analytical approach that is attentive to them.

\section{Generalizing across cases to gain insights into regional processes}

One of my current research projects examines community supported agriculture (CSA) in California. CSA is an ecologically sensitive style of agriculture in which members make commitments in advance to purchase shares of a farm's produce. More than one hundred farmers responded to our survey, the first part of the study, and with this data we've found regional coherence in how CSA is practiced, and that in California at least, it differs in important ways from definitions of CSA commonly espoused in popular and academic writing. For example, 61 percent of farms (59 of 97) disagree or strongly disagree that "the farm shares production risk with members", which is a central tenet to the CSA concept since its inception. We have traced this to a history of CSA implementation in California in which farmers had a challenging time sharing production risk with members (Galt 2013a: 344), but farmers' responses about not sharing risk is also negatively correlated with competition, meaning that farmers in more competitive markets are less likely to be sharing risk with their members (Galt et al. 2015). The particular regional dynamics of alternative food networks (AFNs) is the next frontier for this research, as our data show that CSAs within the different regions of California vary greatly in sharing risk, hosting farm events, and setting pre-payment periods, as well as in terms of farmer satisfaction - farmers in southern California are the most dissatisfied, while farmers in rural northern California are the most satisfied (Galt 2015). Future research could examine the 
same relationships in other regions, which would allow for understanding what is driving regional differences and similarities. Based on my own experience, it would seem that it is both possible and desirable to generalize across cases to gain insights into regional processes; indeed, comparisons allow for one of the strongest ways to explain differences between regions.

Thinking about cases differently, work by numerous political ecologists has focused on the regional political ecology of the Sierra Nevada foothills of California (Filan 2011; Hiner 2014; Hurley and Walker 2004; Walker and Fortmann 2003; Walker and Hurley 2004; Walker, Marvin, and Fortmann 2003). These are often done using the county level as a fluid boundary for the study region, but with clear knowledge that it is nested within the larger region of the Sierra Nevada foothills. Having overseen some of this research as a faculty advisor, I've witnessed discussions of whether this research can be synthesized and compared in useful ways. There are important methodological questions involved in whether one can compare these various cases, all of which were investigated with regional political ecology as a framework, but with different specific research questions and foci. I'd suggest giving it a try, perhaps by being extremely open with qualitative datasets so that similar questions can be posed of each set. How this would hold up under peer review is a good question, since the research design would be post hoc, but perhaps important lessons could be gleaned, and it may produce insights into meta-analyses of qualitative fieldwork data.

Scaling up the concept of cases even more to nation states as cases within world regions (a classical regional approach within geography), we can also conduct analyses that compare and contrast regional processes within different countries. For example, in an analysis of illegal pesticide residues on produce imported into the United States, countries within the same world regions had remarkably different violation rates, suggesting that within-country processes were heavily shaping the producers' compliance with regulations (Galt 2010). I've recently started a research project on cacao/chocolate commodity chains. I'm interested in the socio-ecological effects of direct trade (as increasingly done by new artisan chocolatiers like Amano, Askinosie, Dandelion, and Tcho, to name a few), fair trade, ecological certifications, and bean-to-bar in developing countries (like Kallari in Ecuador and Madécasse in Madagascar), especially as compared to conventional cacao commodity chains. Cacao production systems vary from a very diverse agroforestry system under a tropical forest canopy to a full-sun, highly external-input-dependent production system (Rice and Greenberg 2000). Thus, the ways that the commodity chain intersects with capital, states, producer organizations, households, and the environment varies considerably. Secondary data analysis shows considerable variation in yields around the tropics, likely caused by production practices (including variations in inputs, shade cover, and intercropping), regional and local disease burdens, and varietals planted. Average yield per hectare in 2012 for the world's 58 cacao-producing countries is $475 \mathrm{~kg} / \mathrm{ha}$, while ranging three orders of magnitude from 2,706 kg/ha in Guatemala (the world's highest) to $52 \mathrm{~kg} / \mathrm{ha}$ in the Central African Republic (the world's lowest) (Food and Agriculture Organization 2014). Five nations from different world regions have yields higher than $800 \mathrm{~kg} / \mathrm{ha}$ - Guatemala, Thailand, Saint Lucia, Tanzania, and Madagascar - while 17 similarly disparately located nations have yields less than half the world average (Food and Agriculture Organization 2014). This tremendous variation certainly hides variation between regions within the same country, but it also points to likely similarities in production systems within countries, which is heavily influenced by state development policies as well as the workings of specific commodity chains and where they touch down and interact with the biophysical environment. Thus, important political ecological questions remain to be asked and answered based on considerable regional variation in cacao. In this case, inter-regional and intra-regional comparisons will be useful to understand the dynamics driving these differences.

\section{Future regional approaches for political ecology of agrifood systems}

I'd like to see a regional political ecology with a reinvigorated relationship with agrifood systems (see also Galt 2013b), especially with attention to production and how this connects to consumption and the various actors that shape it. Below are questions I think could help shape this investigation into agrarian capitalism through a regional political ecology lens: 
- What processes - social, ecological, and socio-ecological - are driving agrarian change, and how do they intersect and modify each other within specific regions, i.e., by negating each other, acting synergistically, modifying impacts, etc.?

- What are the possibilities and constraints created by the regional biophysical environment, in terms of what can grow where based on temperature and rainfall, how pests and diseases affect crops? Equally important, how have households, communities, the state, and capital shaped the productive conditions of the land (e.g., through irrigation infrastructure, terracing, roads, etc.)?

- What role does off-farm capital have in shaping agricultural production, specifically in the form of landlords (households and corporations as landholders), finance capital (banks, etc.), input provisioning (fertilizers, pesticides, machinery, etc.), buyers of raw agricultural commodities (especially through quality and food safety standards), commodity markets (prices and their fluctuations), distributors and retailers, and other inputs and outputs of agrifood systems?

- How does the state support, hinder, prevent, or otherwise mediate the various facets of offfarm capital and their relationships to farmers? What other direct and indirect roles do the state and its various agencies play? Blaikie and Brookfield (1987: 17) also rightly noted their "...concern with the role of the state. The state commonly tends to lend its power to dominant groups and classes, and thus may reinforce the tendency for accumulation in these dominant groups and marginalization of the losers, through such actions as taxation, food policy, land tenure policy and the allocation of resources."

- What is the role of households and/or capitalist firms in the direct production of raw agricultural commodities, and how have these changed over time? How do ideologies and subjectivities shape the ways in which direct producers engage in production?

- How do the assemblages of the agrifood system impinge upon the environment at the field, farm, and regional level? How do extra-regional impacts manifest within regions? In what ways do these environmental effects impact producer societies?

In short, this is a call to use regional political ecology to examine the state-capital-householdenvironment "quadrilectic", in other words the various relations between these four overlapping domains, all of which are important to conceptualize as internally heterogeneous and mutually constitutive. Detailed case studies, as have been very common in regional political ecology, can be of use, but larger lessons to inform and transform policies at various levels will need to come out of rigorous comparative work scaled up in the form of a networked regional political ecology (drawing on threads from Birkenholtz 2011; Galt 2010), which should be pursued by political ecologists and allies in agroecology and landscape ecology. That would be one front through which some political ecology can be useful (Blaikie 2012) in efforts to preserve farm household livelihoods, farmland ecologies supportive of a number of other species, and regional ecosystems in the face of the onslaught of "development" in the service of economic expansionism that is at the heart of capitalism.

\section{References}

Birkenholtz, T. 2011. Network political ecology: method and theory in climate change vulnerability and adaptation research. Progress in Human Geography 36(3): 295-315.

Blaikie, P.M. 1985. The political economy of soil erosion in developing countries. London: Methuen.

Blaikie, P.M. 2012. Should some political ecology be useful? The Inaugural Lecture for the Cultural and Political Ecology Specialty Group, Annual Meeting of the Association of American Geographers, April 2010. Geoforum 43(2): 231-239.

Blaikie, P.M. and H.C. Brookfield. 1987. Land degradation and society. London: Methuen. 
Filan, T.R. 2011. Invisible farmers, invisible farms: gender and agriculture in two northern California counties. PhD dissertation. Geography Graduate Group, University of California, Davis.

Food and Agriculture Organization. 2014. FAOSTAT database. Rome: FAO [accessed October 1 2014]. Available from http://faostat.fao.org/site/291/default.aspx.

Galt, R.E. 2010. Scaling up political ecology: the case of illegal pesticides on fresh vegetables imported into the United States, 1996-2006. Annals of the Association of American Geographers 100(2): 327-355.

Galt, R.E. 2013a. The moral economy is a double-edged sword: explaining farmers' earnings and selfexploitation in Community Supported Agriculture. Economic Geography 89(4):341-365.

Galt, R.E. 2013b. Placing agrifood systems in first world political ecology: a review and research agenda. Geography Compass 7(9):637-658.

Galt, R.E. 2014. Food systems in an unequal world: pesticides, vegetables, and agrarian capitalism in Costa Rica. Tucson: University of Arizona Press.

Galt, R.E. 2015. Place-based agrifood systems: a regional analysis of community supported agriculture (CSA) in California. Presented at ATINER Annual International Conference on Geography, June 1. Athens, Greece.

Galt, R.E., K. Bradley, L. Christensen, J. Van Soelen Kim, and R. Lobo. 2015. Eroding the community in community supported agriculture (CSA): competition's effects in alternative food networks in California. Sociologia Ruralis. In press.

Glacken, C.J. 1967. Traces on the Rhodian shore: nature and culture in Western thought from ancient times to the end of the eighteenth century. Berkeley: University of California Press.

Hiner, C.C. 2014. "Been-heres vs. come-heres" and other identities and ideologies along the rural-urban interface: a comparative case study in Calaveras County, California. Land Use Policy 41:70-83.

Horst, O.H. 1987. Commercialization of traditional agriculture in highland Guatemala and Ecuador. Revista Geográfica del Instituto Panamericano de Geografía e Historia 106:5-18.

Hurley, P.T., and P.A. Walker. 2004. Whose vision? Conspiracy theory and land-use planning in Nevada County, California. Environment and Planning A 36(9):1529-1547.

Lowdermilk, W.C. 1953. Conquest of the land through 7,000 years. Washington, D.C.: U.S. Department of Agriculture, Soil Conservation Service.

Marsh, G.P. 1998. Man and nature: or, physical geography as modified by human action. Cambridge: Belknap Press of Harvard University Press.

McKinnon, I. and C.C. Hiner. 2016. Does the region still have relevance? (Re)considering "regional" political ecology. Journal of Political Ecology 23:115-122.

Rice, R.A., and R. Greenberg. 2000. Cacao cultivation and the conservation of biological diversity. Ambio 29(3):167-173.

Robbins, P., and K.M. Bishop. 2008. There and back again: epiphany, disillusionment, and rediscovery in political ecology. Geoforum 39(2): 747-755.

Sauer, C.O. 1938. Destructive exploitation in modern colonial expansion. In Comptes Rendus du Congrès International de Géographie Amsterdam Tome Deuxième (Travaux de la Section III C, Géographie Coloniale). Pp. 494-499. Spanish translation

Stanislawski, D. 1970. Landscapes of Bacchus: the vine in Portugal. Austin: University of Texas Press.

Thomas, W.L., C.O.Sauer, M. Bates, and L. Mumford (eds.) 1956. Man's role in changing the face of the earth. Chicago: University of Chicago Press.

Walker, P.A. 2003. Reconsidering 'regional' political ecologies: toward a political ecology of the rural American West. Progress in Human Geography 27(1):7-24.

Walker, P.A. and L. Fortmann. 2003. Whose landscape? A political ecology of the 'exurban' Sierra. Cultural Geographies 10:469-491. 
Walker, P.A. and P.T. Hurley. 2004. Collaboration derailed: the politics of "community-based" resource management in Nevada County. Society and Natural Resources 17(8):735-751.

Walker, P.A., S.J. Marvin, and L.P. Fortmann. 2003. Landscape changes in Nevada County reflect social and ecological transitions. California Agriculture 57 (4):115-121.

Walker, R.A. 2004. The conquest of bread: 150 years of agribusiness in California. New York: New Press.

Zimmerer, K.S. 1996. Ecology as cornerstone and chimera in human geography. In Earle, C., K. Mathewson and M.S. Kenzer (eds.) Concepts in human geography. London: Rowman and Littlefield. Pp. 161-188.

Zimmerer, K.S. 1999. Overlapping patchworks of mountain agriculture in Peru and Bolivia: toward a regional-global landscape model. Human Ecology 27(1):135-165. 